\title{
Dangerous Iowa Women: Pacifism, Patriotism, and the Woman-Citizen in Sioux City, 1920-1927
}

\author{
KIM E. NIELSEN
}

IN MAY 1927 Elizabeth Hutton of Sioux City, Iowa, appealed to Jane Addams for assistance. Hutton hoped that Addams, the prominent cofounder of Chicago's Hull House and president of the Women's International League for Peace and Freedom (WILPF), would be able to help her and her colleagues. The local WILPF chapter was encountering difficulties. "That we are having a rather hard time of it is putting it mildly," Hutton wrote. "The American Legion and D.A.R. would shoot us at sunrise some glad morning if they had their way. ... Don't fail us," she implored. "We are about on our last legs."1

The dispute in Sioux City - which included the WILPF, the Daughters of the American Revolution (DAR), the American Legion, and the League of Women Voters - illustrates the vigorous debate that took place in the 1920s about the public role and political participation of the newly enfranchised female citizen. As part of their exercise of citizenship, the women of the Sioux City WILPF sought to transform the workings of international politics, bring about disarmament, and end warfare. Local opponents of the WILPF-largely World War I veterans who were members of the local American Legion-thought such goals were

1. Elizabeth (Mrs. Thomas B.) Hutton to Jane Addams, 19 May 1927, Records of the Women's International League for Peace and Freedom - United States Section, 1919-1959, Swarthmore College Peace Collection, Swarthmore, PA.

THE ANNALS OF IOWA 56 (Winter/Spring 1997). CThe State Historical Society of Iowa, 1997. 
radical, un-American, and outside the realm of female expertise. Instead, they praised women who exercised female citizenship in ways that bolstered community veterans and national military strength. According to opponents of the WILPF, women's political involvement was safe only when contained within narrow boundaries. When women advocated disarmament or the curtailment of military training, or when they questioned men's superior judgment regarding questions of national defense, their political activism extended beyond these boundaries, and their opponents were quick to equate their actions with subversion and social upheaval.

This story is not, however, simply one of men against women. Sioux City women disagreed among themselves about the proper exercise of female citizenship and patriotism. Local and state DAR officials sided with the Sioux City American Legion in its effort to halt local WILPF organizing. WILPF women soon battled DAR women over control of the local affiliate of the League of Women Voters. That struggle was important, for the League of Women Voters was the organization locally and nationally dedicated to educating the newly enfranchised female citizen. At stake was the public construction of the civic female, about which Sioux City women did not agree.

This story is further complicated by generational and class politics. The Sioux City WILPF activists were educated, older women of the Progressive generation, with money and social standing. Their local detractors were young World War I veterans, still working to secure professional and personal reputations and financial security. While the small group of Sioux City WILPF women were determined, the national political context and the strength of the local American Legion served to defeat them handily.

IN APRIL 1926 Sarah R. Christy, a field organizer for the WILPF, came to the northwestern Iowa town of Sioux City, which by 1925 had a population of 76,411 , as part of a drive to establish new branches in the Midwest. The WILPF was only one of a number of peace and pacifist organizations with growing influence in the 1920s. It was already clear that World War I had not brought the lasting peace and international democracy 
for which many Americans had hoped. An unprecedented number joined organizations with the goal of outlawing war and pursuing global disarmament. These organizations ranged from the conservative Carnegie Endowment for International Peace to more aggressive pacifist groups; some groups were maledominated and others were for females only. The National Council for the Prevention of War, a coalition of thirty organizations, claimed a membership of millions. The U.S. movement culminated in the 1920s with the ratification in 1928 of the Kellogg-Briand Pact, a 62-nation treaty condemning war. ${ }^{2}$

As part of this growing movement, the Women's International League for Peace and Freedom was founded in 1919, the same year as the American Legion, by an international coalition of suffragists, some of them socialists, all of them long interested in pacifism and newly dismayed by the destruction and violence of World War I. WILPF members justified their involvement in questions of war by relying on essentialist notions of womanhood which emphasized women's caretaking, lifegiving, and nurturing capabilities. Furthermore, they argued that women's unique experiences with the oppression of war gave women political legitimacy. With Jane Addams as its international president, the WILPF endorsed peace, human rights, the League of Nations, and eventual universal disarmament. In the United States, members established an office in Washington, D.C., in order to begin effective lobbying. In 1920 there were five hundred members; by 1923, the organization had grown to include more than five thousand. While relatively small, the WILPF was highly visible and legislatively influential. Two of its leaders were to win Nobel Prizes for Peace: Jane Addams in 1931 and Emily Greene Balch in $1946 .^{3}$

2. Paul L. Murphy, The Meaning of Freedom of Speech: First Amendment Freedoms from Wilson to FDR (Westport, CT, 1972), 189-90.

3. Carrie A. Foster, The Women and the Warriors: The U.S. Section of the Women's International League for Peace and Freedom, 1915-1946 (Syracuse, NY, 1995), chaps. 1 and 2 and p. 45; Harriet Hyman Alonso, Peace as a Women's Issue: $A$ History of the U.S. Movement for World Peace and Women's Rights (Syracuse, NY, 1993), 81-83, 90-93. For other sources on the WILPF, see Gertrude Bussey and Margaret Tims, Pioneers for Peace: Women's International League for Peace and Freedom, 1915-1965 (London, 1980); Catherine Foster, Women for All Seasons: 
Sarah Christy's visit to Sioux City in 1926 coincided with congressional hearings on the Welsh Bill, a WILPF-endorsed proposal to abolish compulsory military training at many of the nation's high schools and colleges. The military and its supporters were on the defensive; they charged that the WILPF was being manipulated by the Russians. Christy and the women she recruited apparently knew that their activities would be controversial. For two weeks she conducted "a quiet campaign," culminating in an organizational meeting to which newspaper reporters were denied admission; the only public recruiting was done at meetings of the Woman's Christian Temperance Union and the Parent-Teacher Council. ${ }^{4}$

The small group who joined the Sioux City WILPF consisted of prominent local women. All were above 40 years of age, most above 50, the majority had gone to college, and all, whether married, widowed, or single, were financially comfortable. Many had locally prominent husbands; these included a pastor, an investment banker, a dentist, a lawyer, a city official, and several owners of large businesses. Several of the women were themselves professionals; Elizabeth Countermine was a physician, and Gertrude Eaton was a local principal. ${ }^{5}$

The reaction of Sioux City residents to the formation of a local chapter of the WILPF in their midst was immediate. The Sioux City Daily Tribune published two articles condemning

The Story of the Women's International League for Peace and Freedom (Athens, GA, 1989); Susan Zeiger, "Finding a Cure for War: Women's Politics and the Peace Movement in the 1920s," Journal of Social History 24 (1990), 69-86. Very little has been published on local WILPF groups; see Joan M. Jensen, "Helen Marston and the California Peace Movement, 1915-1945," California History 67 (1988), 118-31; Kimberly Schmidt, "The North Newton Women's International League for Peace and Freedom: Educating for Peace," Mennonite Life 40 (1985), 8-13.

4. Sioux City Daily Tribune, 12 April 1926; Foster, The Women and the Warriors, 113-15.

5. I have identified twelve women as members of the WILPF: Elizabeth (Mrs. J. H.) Andress, Helena (Mrs. C. Walter) Britton, Elizabeth (Mrs. Robert) Countermine, Gertrude Eaton, Leonne (Mrs C. Fred) Gould, Catherine (Mrs. J. G.) Herman, Laura (Mrs. H. Harvey) Holmes, Emily (Mrs. Charles A.) Hoyt, Bertha (Mrs. Thomas B., known as Elizabeth) Hutton, Del Gracia (Mrs. Ebenezer) Lewis, Adaline Lewis, and Frances (Mrs. Milton P.) Smith. The personal information about these women has been gathered from the 1925 Iowa Census and city directories from 1910, 1915, 1920, 1925, and 1926. 
women's peace groups. In one article a lecturer warned that "Women's peace clubs ... may have some well-meaning members, but if they knew who was back of the movement, they would shrink from ever again taking part in the meetings." ${ }^{\prime 6}$ The published reaction that was to have the most consequence, however, was in the April issue of the Sioux City American Legion's Monahan Post News. The post's monthly publication, a professional-looking magazine, was edited by Jesse E. Marshall, a local attorney and chairman of the Iowa American Legion's Americanism Commission. Local commander Stanley G. Eaton urged members to read the issue and then "pass it on to some friend who has need of the information it contains. ${ }^{\prime 7}$

The magazine warned that a local chapter of "the notorious Women's International League for Peace and Freedom" had recently been organized in Sioux City. While the women involved were "the outstanding women of Sioux City whose patriotism is unquestioned," it was believed that they had been "deceived by the 'wolf in sheep's clothing."' The author of the newsletter was confident that "as soon as they learn what the organization really is and stands for, they will immediately withdraw from membership." The WILPF, he charged, was "one of the most vicious and unpatriotic organizations in the United States." It was "directly affiliated with the Communist Government of Russia" and was financially affiliated with individuals who advocated immoral sexual behavior. In the wake of such charges, the Sioux City American Legion passed a resolution condemning the WILPF and all efforts to promote disarmament or to limit military education in schools. On May 7, 1926, the Iowa Legionaire expressed confidence that the Monahan Post had "presented the true American peace-with-honor position so masterfully" that the Sioux City WILPF would "speedily die."

\section{Sioux City Daily Tribune, 16, 17 April 1926.}

7. A typed and mimeographed copy of the April 1926 Monahan Post News is attached to a letter from Dorothy Detzer to Jane Addams, 22 November 1926, Jane Addams Papers, Series 1, Swarthmore College Peace Collection. Only a small number of issues of the Monahan Post News are extant. The November 1923 issue was a 64-page professionally published magazine. I assume that it was similar in 1926 .

8. Ibid.; Iowa Legionaire, 7 May 1926. 
LOCAL AMERICAN LEGION CONCERNS about the WILPF resonated with the larger political culture of antiradicalism in the 1920s. Beginning in 1923, women's organizations involved in peace efforts and progressive political reform suffered a series of public attacks in which militarists, the War Department, manufacturers' organizations, and self-proclaimed patriot organizations accused them of radicalism. In one of the most prominent examples, the WILPF and the Women's Joint Congressional Committee, the largest lobbying coalition of women's groups, figured prominently in various versions of the widely distributed Spider Web Chart, which drew links between as many as seventeen women's organizations and twenty women, claiming that they were part of a concerted plan to promote international socialism. Other groups implicated by the chart included the League of Women Voters, the General Federation of Women's Clubs, the Young Women's Christian Association, and the Woman's Christian Temperance Union. The chart was headed with a quotation from the 1919 Lusk Report on Radicalism: "The Socialist-Pacifist Movement Is an Absolutely Fundamental and Integral Part of International Socialism." The wide distribution of the spider web charts confirmed suspicions in the minds of many regarding the political activities of American women, and the Sioux City American Legion's charges against the WILPF capitalized on those suspicions. ${ }^{9}$

Concerns about radicalism and women's expressions of citizenship reverberated in many contexts. In the book Peace at Any Old Price, the president of the American Defense Society, Richard Merrill Whitney, claimed that the WILPF was linked to the radical labor group, the Industrial Workers of the World (IWW). Furthermore, Whitney charged that the WILPF's national convention of 1923 was "probably the most subversive, certainly the most insidiously and cleverly camouflaged, thoroughly anti-

9. For discussions of the Spider Web Chart, see Joan M. Jensen, "All Pink Sisters: The War Department and the Feminist Movement in the 1920s," in Decades of Discontent: The Women's Movement, 1920-1940, ed. Lois Scharf and Joan M. Jensen (Boston, 1983), 199-222; Murphy, The Meaning of Freedom of Speech, 192-94; Nancy F. Cott, The Grounding of Modern Feminism (New Haven, CT, 1987), 242, 249-50; J. Stanley Lemons, The Woman Citizen: Social Feminism in the 1920s (1973; reprint, Charlottesville, VA, 1990), 215-18. 
The Socialist-Pacifist Movement in America Is an Absolutely Fundamental and Integral Part of International Socialism (Lask Report Pate 11.)

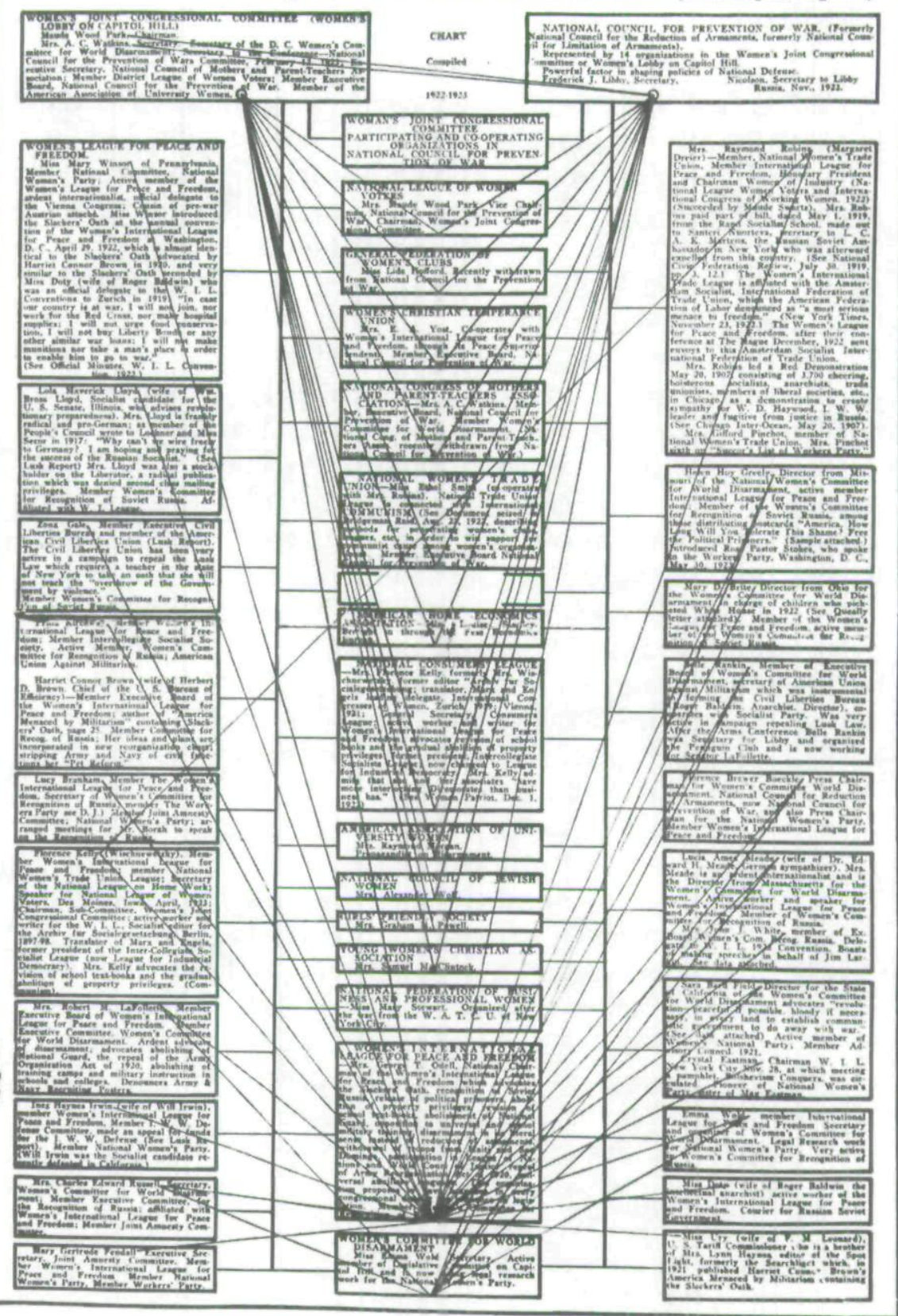

Spider-Web Chart, 1924. In an earlier version of this chart, the Daughters of the Revolution filled the blank space in the middle. 
American and un-American public meeting that has been held in this country since the United States entered the European war." The conference was dominated, Whitney insisted, "by the spirit of Russian communism." Whitney claimed that there were many dangerous elements on the WILPF agenda. The internationalism of the organization suggested a lack of love for its members' own country and an inclination toward Communism. The appeals for disarmament were part of an effort to ease the Communist takeover. Advocacy of U.S. recognition of the Soviet Union meant endorsement of Communism. ${ }^{10}$

The charges of Whitney's Peace at Any Old Price, underlined by his claims of ties between the WILPF and the IWW, may have resonated unusually well in Sioux City. A copy of the book probably made it to Sioux City. Mrs. Anthony Wayne Cook, the President General of the DAR, thought the book praiseworthy and sent copies of it to all DAR state regents and national officers. As Francesca Morgan shows in an accompanying article, Iowa DAR members enthusiastically joined the ranks of antiradicals in the 1920s. ${ }^{11}$ Iowa's state regent at the time was Kathryn Munger, a Sioux City resident who would later speak against the WILPF at a district convention of the American Legion in Sioux City.

In the 1920s the Sioux City Monahan Post was a large post prominent in the Iowa American Legion, which in turn was prominent in the national Legion. The Monahan Post's membership reached 1,600 in 1926, when it received a statewide service club trophy. Its band won national prizes. Several members, among them lawyer Jesse Marshall and Sioux City Tribune editor John Kelly, were or had been state or national committeemen. Throughout the 1920s, the Monahan Post was always one of the three largest posts in the state. And during that decade the Iowa

10. Richard Merrill Whitney, Peace at Any Old Price (New York, 1923), 3.

11. Mrs. Anthony Wayne Cook to Ralph Easley, box 27, general correspondence files, National Civic Federation Papers, Rare Books and Manuscript Division, New York Public Library; Francesca Morgan, "'Regions Remote from Revolutionary Scenes': Regionalism, Nationalism, and the lowa Daughters of the American Revolution, 1890-1930," in this issue. 
Department of the Legion often led the nation in membership statistics. ${ }^{12}$

The American Legion had been formed in 1919 by World War I servicemen and immediately involved itself in policing the postwar Red Scare. Throughout the mid-1920s, with Communists and Socialists harder to find, the Legion turned its attention to "pacifists," who it argued "sought to pave the way for a Communist conquest by disarming America." On a national level, the American Legion worked with the Daughters of the American Revolution, the Department of Justice, and the War Department to supply information on subversive activities throughout the United States. ${ }^{13}$

The Iowa American Legion joined in actively condemning disarmament proposals and pacifism and women's involvement in those campaigns. In 1925 the Iowa City American Legion post commander told the Davenport second district conference that "The red, the pink and the peace-at-any-price pacifist are all alike." In 1926 prominent Iowa Legion member and Assistant Secretary of War Hanford MacNider reviled "all forms of 'sob sister' pacifism" as dangerous, and ridiculed Jane Addams and Carrie Chapman Catt, who, as women, claimed authority to criticize war. In March 1926 the Sioux City American Legion entered the debate and condemned the efforts of national peace advocates to curtail military training in schools as "the work of Russian bolshevists," "unpatriotic and un-American."14

Sioux City had prior experience with "subversives" in its midst. During the administration of three-term mayor Wallace Short, a Labor Party progressive, the IWW, also known as Wob-

12. Proceedings of the Ninth Annual Convention of the Iowa Department of the American Legion, 15-17 August 1926, box 1, American Legion Papers, State Historical Society of Iowa; Jacob Armstrong Swisher, The American Legion in Iowa, 1919-1929 (Iowa City, 1929). The size, relative national prominence, and increasingly antiradical stance of both the American Legion and the DAR in Iowa reinforces Francesca Morgan's claims about the conservatism and antiradicalism of postwar Iowa. Morgan, "'Regions Remote.'"

13. William Pencak, For God and Country: The American Legion, 1919-1941 (Boston, 1989), 146, 160-65.

14. Iowa Legionaire, 25 December 1925, 5 February 1926, 5 March 1926; Des Moines Register, 24 February 1926; New York Times, 19 March 1926; Sioux City Tribune, 26 March 1926. 
blies, held conventions in the city (at which Short spoke). The gatherings of the IWW in Sioux City meant that Wobbly and Socialist speakers often came through town in the early 1920s. Because of the town's reputation, Sioux City's Legionnaires were prevented from hosting the 1920 state convention; other Legionnaires were unwilling to visit a town "not one hundred percent American." The local Legionnaires were determined to contest the town's reputation, and Christy's visit to recruit members for the WILPF became a convenient target. ${ }^{15}$

\section{IN THE WAKE OF THE LEGION'S ATTACK on the local} WILPF, the organization pursued two responses. First, Adaline Lewis, secretary of the Sioux City WILPF, apparently wrote to the local Legion post. Jesse Marshall, the editor of the post's magazine, responded. He apologized for "mistakes" and "unintentional unkindnesses," but added, "I am satisfied . . . that I can convince you, or any fair-minded woman, that every word said about this League and its purposes and past history is strictly and literally true." Marshall scolded the women: while men "are making sacrifices in the interest of national safety ... . you and your friends are hampering our efforts." He went on to warn that their efforts to abolish military training in schools would not make war less likely, but rather "make it infinitely more horrible and costly."16

The local WILPF women also turned to the national WILPF for assistance. Elizabeth Hutton went to the national convention in the summer of 1926 and stopped at the Washington, D.C., office for advice. At the end of July, Adaline Lewis requested that Dorothy Detzer, the League's executive secretary, visit Sioux City. "We are not making much progress," she asserted. In a statement implying that the American Legion was not their

15. William H. Cumberland, Wallace Short: Iowa Rebel (Ames, 1983), 59-60; idem, "Plain Honesty: Wallace Short and the I.W.W.," Palimpsest 61 (1980), 146-60. The IWW and the American Legion clashed both locally and nationally. In Centralia, Washington, five men died in one such clash. See Pencak, For God and Country, 149-52.

16. Jesse Marshall to Adaline Lewis, 21 May 1928, attacks folder, Hannah Clothier Hull Papers, 1889-1958, Swarthmore College Peace Collection. 
only problem, she wrote that WILPF members were taking time to educate themselves in order to debate the issues "with our D.A.R. friends who are so bitterly opposed to the League and win them over." ${ }^{17}$

At the end of October, Detzer came to Sioux City. Detzer was a skilled negotiator who later became a well-known national figure for her extensive lobbying and leadership skills. While she was in town, Detzer met privately with the editors of both local newspapers, and thirty women held a public meeting at the Davidson tea room to discuss the WILPF's plans. What must have been a much more contentious meeting took place in Jesse Marshall's office. There Detzer met with Marshall, post commander Stanley Eaton, and five local WILPF members. Detzer was a contemporary of the two men; the Sioux City women were all a generation or two older. ${ }^{18}$

Detzer's notes on the meeting indicate that she took clear command. She began by expressing her admiration for the American Legion, telling of her brothers who had served in World War I and their membership in the American Legion. She then went over the article in the April Monahan Post News one sentence at a time, occasionally word by word. Later, Detzer characterized the closing of the meeting as very friendly. Eaton agreed to print a retraction as well as anything Detzer might write in the next issue of the Monahan Post News. ${ }^{19}$

The retraction, however, did not appear as anticipated. The Sioux City WILPF members, according to Detzer, were "so excited about the retraction that they went around bragging about it." Consequently, the Monahan Post's executive committee met and resolved that despite reports "being circulated to the effect that Monahan Post has withdrawn its opposition to the Women's International League for Peace and Freedom," the post "hereby reaffirms" its belief that the activities of the WILPF are "disloyal, unpatriotic and inimical to the national safety." ${ }^{10}$

17. Adaline Lewis to Dorothy Detzer, 27 July 1926, attacks folder, Hull Papers.

18. Sioux City Tribune, 30 October 1926.

19. Dorothy Detzer to Jane Addams, 22 November 1926, Jane Addams Papers, series I, Swarthmore College Peace Collection.

20. Ibid.; Sioux City Tribune, 4 November 1926. 
The 11th District of the Iowa American Legion, at its convention in Sioux City the following week, repeated the local post's assertions. At the convention, state officials and local members issued "scathing denunciations of the activities of radicals and their organizations." Complaining that the Sioux City WILPF was "aggressively seeking members and spreading propaganda," convention attendees resolved to condemn the WILPF. Sioux City resident and state League of Women Voters vice-president Eloise Ruff attended the meeting and endorsed the resolution; Kathryn Munger, Sioux City resident and state regent of the Daughters of the American Revolution, did the same. Within the next months at least one other Iowa American Legion district endorsed the same resolution. ${ }^{21}$

Attacks on the WILPF and others advocating disarmament spread throughout Iowa during the summer and fall of 1926. The Iowa American Legion's executive committee appointed a special group to "study peace and peace-at-any-price propaganda." Margaret Hinderman, state president of the American Legion Auxiliary, spoke out against the League as did several local auxiliary units. In the fall, the American Legion's National Commander warned Iowa members attending the state convention that a "flood of pacifist propaganda was being released all over the nation." ${ }^{22}$ Ferre C. Watkins, commander of the Illinois American Legion, whom the Iowa Legionaire called "one of the greatest speakers in the American Legion," denounced WILPF president Jane Addams in a highly publicized speech. Addams's Chicago Hull House, he claimed, "is the rallying point of every radical and communistic movement in Chicago." These charges were reprinted in the Iowa Legionaire and Sioux City papers. Watkins personally visited Mason City, Iowa, where he warned that "reds are worming their doctrines into many churches and women's organizations under the guise of pacifism. ${ }^{\prime 23}$

21. Sioux City Journal, 13 November 1926; Iowa Legionaire, 19 November 1926; Sioux City Tribune, 10 December 1926; Des Moines Register, 10 December 1926.

22. Proceedings of the Eighth Annual Convention of the Iowa Department of the American Legion, 15 September 1926, p. 122, American Legion Papers.

23. Iowa Legionaire, 3 and 17 December 1926; Sioux City Tribune, 11 November 1926. See also Allen F. Davis, American Heroine: The Life and Legend of Jane Addams (New York, 1973), 266. 
Detzer and the local women responded to the repeated charges. The Sioux City women sent Detzer the Legion's resolution against the WILPF, which had appeared following her visit. Detzer then appealed to Stanley Eaton to publish her statement correcting "definite misstatements of facts" and reminding him that he had twice given her his word. ${ }^{24}$ Apparently a retraction was published in the Monahan Post News, but as Detzer characterized it, it was done "with a good deal of bitter comment and many inaccuracies." In December Detzer wrote a letter to the Des Moines Register. "We are hoping," she wrote, "that the friends of peace will help to show up the childishness of these men who have never grown up nor developed a sense of humor." A WILPF publication repeated Detzer's theme, and in reference to what was called "the situation in Sioux City," the WILPF claimed that the attacks on it were "the result of the boyish sentimentality of some of the Legion men ... incapable of clear thinking on national issues." ${ }^{25}$

In turn, Jesse Marshall ridiculed Detzer and the Sioux City members of the WILPF. Their statement, he claimed, "requires no comment to an intelligent and patriotic citizen." The women of Sioux City who had "pledged their efforts to make America defenseless" were merely wasting their time. Detzer's letter to the Des Moines Register, he charged, was an appeal for "free propaganda," filled with "spiteful and false statements." 26

The rest of the story in Sioux City is unclear. In May 1927 Elizabeth Hutton made her appeal for help to Jane Addams. It appears that the Sioux City branch of the Women's International League for Peace and Freedom, which from all available evidence was the first chapter in Iowa, declined into nothing. Women's peace organizations remained in decline until the 1960s, when branches of the WILPF and Women Strike for Peace formed in

24. Dorothy Detzer to Commander S. G. Eaton, 18 November 1926, Records of the Women's International League for Peace and Freedom-United States Section, 1919-1959, series C, box 5, folder 16, Swarthmore College Peace Collection, Scholarly Resources Microfilm Edition, reel 42, frame \#781-82.

25. Report of the Executive Secretary, Executive Committee Meeting, 14 December 1926, series A2, box 1, folder 18, ibid. (reel 5); Des Moines Register, 21 December 1926; Iowa Legionaire, 21 January 1927.

26. Iowa Legionaire, 21 January 1927. 
Iowa City, Cedar Rapids, and Des Moines. The American Legion retained a powerful and visible presence in Iowa.

THIS STORY of ideological conflict is also a story of generational struggles entwined with gender and class issues. World War I had been a pivotal event in the lives of the Sioux City American Legion men. Whether each man experienced warfare or not, the veterans most likely returned home with a strengthened male claim to authority, adulthood, and military expertise. The American Legion men, whose average age was 32, were separated from the WILPF women, whose average age was 53, by both age and their experience of the war. ${ }^{27}$ Detzer's letter to the Des Moines Register, which cited "the childishness of these men who have never grown up," and the wording of the WILPF publication, which mentioned "the boyish sentimentality of some of the Legion men," would only have exacerbated the age divisions. ${ }^{28}$

This was not, however, simply a political generation gap. Generational differences were made more complex because the figures who challenged the young mens' claims to authority were older women. While age may have granted older men respect and a solemn hearing, it only granted the Sioux City WILPF members some condescending indulgence. Their gender handicapped claims to political authority. The situation may have been frustrating to both groups. The WILPF women, with no military experience, old enough to be the mothers of Legion members, were telling young men confident of their political

27. Information on age, home ownership, rental values, and education level was taken from the 1925 Iowa Census for Woodbury County. With a 1923 list of Sioux City American Legion members, I traced information on a randomly chosen 203 Legion members. Of the 203 in my sample, only 2 men were over 40. Post Commander Stanley Eaton was 36 and Jesse Marshall was 37. Because the number of WILPF members is so small, I searched for all of them in the 1925 Census. I was able to locate all but one (Elizabeth Andress). She and her spouse (Pastor John H. Andress of the First Congregational Church) do appear, however, in the 1925 Sioux City Directory. Information on the WILPF members is handicapped by the small size of my sample-12 named women.

28. Des Moines Register, 21 December 1926; Iowa Legionaire, 21 January 1927. A helpful work for theorizing about generations is Alan B. Spitzer, "The Historical Problem of Generations," American Historical Review 87 (1973), 1353-87. 
realism and comprehension of national defense needs what U.S. defense policy should be. At the same time, these young men, young enough to be the sons of WILPF members, were telling educated and established older women how to conduct themselves, disdainfully suggesting that if the women only understood what the young men already knew, the women would change their ways. ${ }^{29}$

Generational and ideological tensions may have been compounded by issues related to class and status. WILPF members were well-educated older women who had financial resources, often connected to local men with financial and career resources, who told well-educated but generally not as well-established young men how citizenship should be interpreted. The WILPF members' relatively high levels of education may have led them to expect some deference from the Legionnaires. An astonishing 70 percent ( 7 of 10 ) of local WILPF members reported attending college, much higher than the 11 percent countywide for women over 18, and more than double the percentage of collegeeducated Legion men. Among Legion members who recorded their education levels on the 1925 Iowa Census, 34 percent (44 of 199) had attended college courses, a percentage that exceeded the countywide average of 13 percent for men over 18 . The high education rates of Legion men suggest that they were differentiated from their peers and that they, too, expected professional and personal prestige in their community. These competing expectations may have added contention to a political conflict between Legionnaires and equally highly educated women who did not automatically accord Legion men the status they expected.

The differential in educational levels was exacerbated by differences in economic standing. There was, for example, a

29. Suffragist Elizabeth Cady Stanton often had been in similar situations and expressed her frustration this way: "In the whole course of our struggle for equal rights I never felt more exasperated than on this occasion, standing before a committee of men many years my juniors, all comfortably seated in armchairs, I pleading for rights they all enjoyed though in no respect my superiors, denied me on the shallow grounds of sex." Elizabeth Cady Stanton, Susan B. Anthony, and Matilda Joslyn Gage, eds., History of Woman Suffrage, 6 vols. (New York, 1969), 3:93. Thanks to Linda Kerber for pointing this out to me. 
marked difference between the value of the homes in which Legion and WILPF members lived. Legion men who rented homes paid an average rent of $\$ 29$ per month; the one WILPF woman who rented paid $\$ 66 .^{30}$ The average county homeowner lived in a home valued at $\$ 5,566$. Legion men were a little above that; those who owned homes had homes with an average value of $\$ 6,443$. WILPF women whose families owned their homes lived in houses with an average value of $\$ 14,500$. This average is somewhat distorted by WILPF member Del Gracia Lewis's ownership of a home valued at $\$ 40,000$; however, all but one WILPF homeowner lived in a home whose value exceeded the Legion average. The marked class and educational differences between WILPF women and Legion men, as well as their age differences, must have aggravated and may have been an integral part of the tension, manifested in politics, between the two groups.

However frustrating the prestige of the local WILPF membership may have been to the local American Legion, the relative wealth, education, community status, and connections of Sioux City WILPF members served to protect the women from the harsher consequences of antiradicalism. None of them were arrested for disloyalty, none were deported, none were denied voting privileges, and none were physically threatened. Sioux City WILPF members voiced their political opinions while simultaneously conforming to and challenging local expectations about female behavior.

American Legion members expressed shock that ideas such as those voiced by the local WILPF chapter could come from women within their own community, particularly such reputable women; it had been easy to blame the radicalism of the IWW on outsiders. Local anti-WILPF sentiments were almost always couched in trivializing declarations that the local women, while really quite fine women, had been duped or were unaware of the consequences of their actions. Legion publications

30. An additional 13 percent of the Legion men (26 of 203) lived as roomers in boarding houses, the YMCA, or with unrelated individual families. None of these men reported their rent in the census. If one were able to take these individuals into consideration, the average value of the rent paid by Legion men would undoubtedly go down. 
and the letters local Legion members wrote to the WILPF chapter were quick to claim that the women involved had only to learn and understand the truth in order to be swayed to the side of the Legion men. Women's natural kindness, and blindness, led them to support disarmament proposals that would bring about Bolshevism. Femaleness handicapped women's exercise of citizenry in such a way that it was best for them to avoid questioning men on issues of war. A general unwillingness to believe in the political acumen and intelligence of the local WILPF women pervaded local Legion discussions.

OPPOSITION TO THE WILPF came not only from the young men of the American Legion but from within women's organizations as well. Although it was the men of the Sioux City American Legion who drew attention to the WILPF, the two women who wrote to national WILPF leaders-Adaline Lewis and Elizabeth Hutton - wrote of difficulties in convincing other women of their beliefs. The enactment of female suffrage had brought women into the male sphere of the electorate, yet WILPF members continued to believe that women's political activities should be based in women's organizations. As the newly enfranchised WILPF women explored and explained their hopes for women's political participation, they sought to convince local women's organizations - such as the League of Women Voters and the Daughters of the American Revolution - to reflect their ideas about disarmament and military training.

This was not a simple task. Sioux City women seeking organizational involvement had a variety of active choices; and in the 1920s local women played prominent roles in the statewide leadership of their respective organizations. For example, Eloise Ruff served as state vice-president of the League of Women Voters, and Kathryn Munger served as state regent of the DAR. WILPF efforts to recruit in the local Woman's Christian Temperance Union and the Parent-Teacher Council suggest that local WILPF members were involved in those women's organizations and that they anticipated a receptive welcome. This wide array of female organizations was a continuation of the larger nineteenth-century women's club movement, 
which sought to bring women together to improve society and themselves. ${ }^{31}$

Despite this shared tradition of club activism, women disagreed about the substance of women's participation in the public sphere. In Sioux City, as in Cincinnati, Seattle, and Huron, South Dakota, contentions among women about women's proper political activities were centered in the local League of Women Voters (LWV). Former suffragists created the LWV after the 1920 passage of woman suffrage in order to educate and shape the transformed female citizen. In the Sioux City League, there were women such as Iowa vice-president Eloise Ruff, who had joined the Legion in condemning the WILPF and women's interest in disarmament, as well as local WILPF members. Such disparate understandings of women's political interests led to tension. As a result, as local WILPF leader and LWV member Elizabeth Hutton reported, "the D.A.R. made a gallant fight and did defeat some who are prominent in the League of Women Voters because they were members of the Peace League." ${ }^{\prime 32}$

Although the Sioux City members of the WILPF, the DAR, and the League of Women Voters were all active public women, a common womanhood did not mean that the women of Sioux City shared political interests. Sioux City WILPF members attempted to use their faith in women's unique political insights to claim political authority and a right to pronounce on foreign policy and war. The women who opposed them used a similar

31. Anne Firor Scott, Natural Allies: Women's Associations in American History (Urbana and Chicago, 1991). Many options were available to Iowa women. For two examples, see the articles by Christine Pawley and Catherine E. Rymph in this issue.

32. Elizabeth (Mrs. Thomas B.) Hutton to Jane Addams, 19 May 1927. Eloise Ruff, state League of Women Voters official and local LWV leader, had been at the American Legion convention that condemned the League, and she had publicly endorsed the resolution. Sioux City Tribune, 19 May 1927. Little has been published on other local Leagues of Women Voters. For an interesting discussion of the early years of the North Carolina League, see Kathryn L. Nasstrom, "'More was Expected of Us': The North Carolina League of Women Voters and the Feminist Movement in the 1920s," North Carolina Historical Review 68 (1991), 307-19. In the DAR, contentious debates over disarmament would lead to the expulsion and resignation of many women in 1927 and 1928. Foster, The Women and the Warriors, 51, 53; Lemons, The Woman Citizen, 120-22; Morgan, "'Regions Remote.'" 
argument about the differences between men and women to question the authority claimed by WILPF members. This incident is a clear example of the historical inaccuracy of referring to women as a cohesive, interest-sharing political group; historians should be aware, in Nancy Cott's terms, of "women's . . . reluctance to say we." Conflicts over understandings of womanhood and the political implications of those understandings were at the core of this local debate. The Sioux City League of Women Voters, the DAR, and the WILPF represented divergent hopes among women for the political character and civic involvement of the female Iowa citizen. ${ }^{33}$

THE MEN OF SIOUX CITY'S AMERICAN LEGION, however, did not see this simply as a battle among women. For them, it was an ideological battle made worse by the possibly disastrous consequences of an unwisely executed female foray into the political sphere. Sioux City WILPF women were allegedly part of "one of the most vicious and unpatriotic organizations in the United States. ${ }^{\prime \prime 4}$ The women's exercise of female citizenship, feared to be on behalf of a Russian-manipulated disarmament movement, was thought radical and dangerous. Deeply held concerns on the part of American Legion men and their female supporters about women's political radicalism and national safety combined with and were exacerbated by generational and class tensions. Finally, the political interests of Sioux City WILPF members stretched the acceptable boundaries of women's participation in the public sphere. The women of the Sioux City WILPF were perceived to be dangerous female citizens not only because they questioned defense policy, but because they entered political arenas in which women were to support-rather than question - male authority.

33. Cott, The Grounding of Modern Feminism, 10.

34. Monahan Post News, April 1926. 
Copyright of Annals of Iowa is the property of State of Iowa, by \& through the State Historical Society of Iowa and its content may not be copied or emailed to multiple sites or posted to a listserv without the copyright holder's express written permission. However, users may print, download, or email articles for individual use. 